\title{
PROMOTION REDUCTION INCREASED MARKET SHARE INSURANCE INDUSTRY IN INDONESIA
}

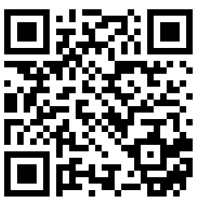

\author{
Muhammad Alfi Fudholi ${ }^{1}$, Umbas Krisnanto ${ }^{*}$ 四 \\ ${ }^{1}$ Management, Perbanas Institute, Indonesia
}

DOI: https://doi.org/10.29121/ijetmr.v7.i9.2020.771

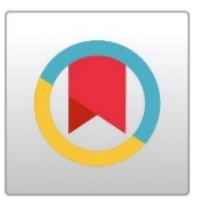

Article Citation: Muhammad Alfi Fudholi, and Umbas Krisnanto. (2020). PROMOTION REDUCTION INCREASED MARKET SHARE INSURANCE INDUSTRY IN INDONESIA. International Journal of Engineering Technologies and Management Research, 7(9), 39-46. https://doi.org/10.29121/ijetmr.v7 i9.2020.771

Published Date: 24 September 2020

Keywords:

Distribution Channels

Promotion Costs

Sales

Market Share

\section{ABSTRACT}

The purpose of this study is to analyze the effects of distribution channels and promotion costs mediated by sales on the market share of life insurance products in Indonesia, a sample of ten insurance companies with the data used is time series data taken from the 2014 annual report of the company and the total insurance industry sales report taken from 2014 - 2018, the analysis technique used is the path analysis technique using two regression equations which are the development of regression analysis and the sobel test to determine indirect effect, the distribution channels mediated by sales have a significant effect which means that if there is an increase in the number of distribution channels there will be an increase in market share, while the promotion costs in mediating the sales have a significant negative effects indicate that the cost reduction a promotion will increase the market share of life insurance companies in Indonesia.

Motivation/Background: Explain reduction promotion will increase the market share of life insurance companies.

Method: Two regression equations analysis and the sobel test to determine indirect effect.

Results: Reduction in promotion will increase market share.

Conclusions: Mediating sales have a significant negative effect indicate reduction a promotion will increase the market share of life insurance companies.

\section{INTRODUCTION}

Along with the increasing growth of the Indonesian financial industry, insurance services have great business potential that until now has not been able to be utilized to the maximum, the total insurance industry gross premium in 2017 reached Rp407.7 trillion with an average growth in the last 5 years of 20, 6 percent, when compared with Indonesia's 2017 population of 261.9 million, an insurance density of Rp1,556,711 which means that every average Indonesian citizen spends Rp1,556,711 to pay a premium every year with the largest portion in the life insurance sector by 47 percent. Based on this phenomenon based on the characteristics of life insurance companies and distribution channel strategy and promotional costs can affect the income of life insurance companies. companies to determine the steps to increase sales owned to increase trust in the company's position in the market.

The variables used in this study are Distribution and Promotion as independent variables and Sales as intervening variable while market share as the dependent variable. 
The sample used in this study is a life insurance company with the highest market share at the end of the research period, which always publishes complete, audited and widely published financial reports during the 20142018 period.

Theoretical background hypotheses development

According to Armstrong and Kotler (2016) Distribution channels are groups of independent organizations that are involved in the process of achieving a product or service in the hands of consumers or users.

Promotion is a series of activities to communicate giving knowledge and convincing people about a product so that he recognizes the greatness of the product, buying and using the product also ties his thoughts and feelings in a form of loyalty to the product.

According to Swastha in Sunyoto (2012), Selling is the science and art of personal influencing by sellers to invite others to be willing to buy the goods or services offered.

According to Berkowitz et al. (2018), Market share is the size of the market share controlled by a company that is measured as a percentage, the way to measure market share is as follows:

Market Share $=($ Total Company Sales $) /($ Total Sales in Industry / Market $) \times 100 \%$

Hypotheses

$\mathrm{H}_{1}$ : Effect Distribution Channels on the Sales of Life Insurance Companies in Indonesia from 2014-2018. Based on Maryatun \& Aryanti (2017) and Andelkovic, Barac and Radosavljevic (2017).

$\mathrm{H}_{2}$ : Effect Promotional Costs on the Proceeds of Sales of Life Insurance Companies in Indonesia from 2014-2018. Based on Syaharudin (2015) and Suryawan (2017)

$\mathrm{H}_{3}$ : Effect Distribution Channels on Market Share with Sales as an intervening variable in Insurance Companies in Indonesia from 2014-2018. Based on Romadhona (2018) and Wilbur \& Farris (2013)

$\mathrm{H}_{4}$ : Effect Promotion Costs on Market Share with Sales as an intervening variable in Life Insurance Companies in Indonesia from 2014-2018. Based on Mathur and Sinitsyn (2013) and Vakratsas (2008).

$\mathrm{H}_{5}$ : Effect Sales on Market Share in Life Insurance Companies in Indonesia from 2014-2018. Based on Moutinho (1988) and Min and Wolfinbarger (2004).

\section{MATERIALS AND METHODS}

Sample Selection Criteria, the number Insurance companies in the Indonesian Life Insurance Expert Association and the Financial Services Authority in the 2014-2018 were 61 companies and Insurance companies published complete financial statement data in the 2014-2018 research period were 51 companies, and Insurance companies that have the highest market share in 2018 as the final year of research were 10 companies.

The models used in this study are: First Equation: $\mathrm{M}=\mathrm{a}+\mathrm{b} 1 \mathrm{X} 1+\mathrm{b} 2 \mathrm{X} 2+\mathrm{e}_{1}$, Second Equation $\mathrm{Y}=\mathrm{a}+\mathrm{b} 1 \mathrm{X} 1+$ $\mathrm{b} 2 \mathrm{X} 2+\mathrm{b}_{3} \mathrm{M}+\mathrm{e}_{2}$

This research data was processed using SPSS 26. Using the classic assumption test, analysis of the coefficient of determination, and hypothesis testing.

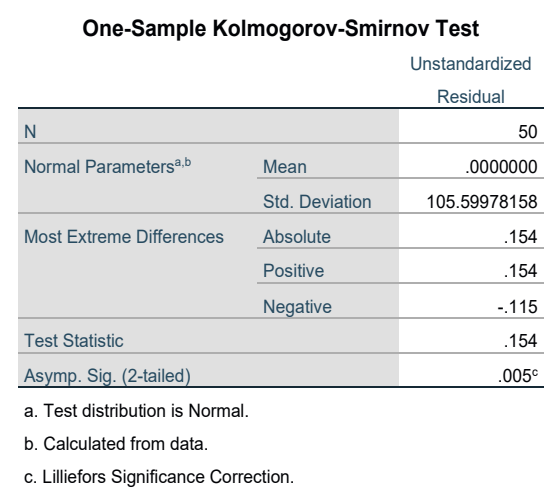

Figure 1: $1^{\text {st }}$ Normality Test

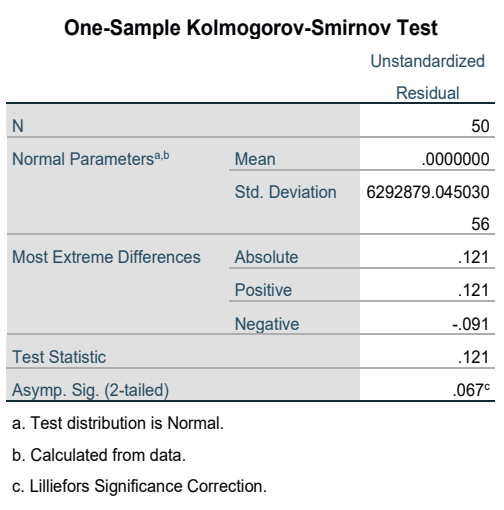

Figure 2: $2^{\text {nd }}$ Normality Test

Source: SPSS 
First normality test states that the significant value addressed in the data processing for the first equation $0.005>0.05$, showed the data are normally distributed. Second Normality Test $0.067>0.05$ showed the data were normally distributed.

Table 1: $1^{\text {st }}$ Autocorrelation Test

\begin{tabular}{|c|c|}
\hline & $\begin{array}{c}\text { Model } \\
\text { Summary }\end{array}$ \\
\hline Model & $\begin{array}{c}\text { Durbin- } \\
\text { Watson }\end{array}$ \\
\hline 1 & 0.613 \\
\hline & \\
\hline a. Predictors: (Constant), \\
PROMOTION, DISTRIBUTION
\end{tabular}

Source: SPSS
Table 2: $2^{\text {nd }}$ Autocorrelation Test

\begin{tabular}{|c|c|}
\hline & $\begin{array}{c}\text { Model } \\
\text { Summary }\end{array}$ \\
\hline Model & $\begin{array}{c}\text { Durbin- } \\
\text { Watson }\end{array}$ \\
\hline 1 & 1.076 \\
\hline $\begin{array}{c}\text { a. Predictors: (Constant), PROMOTION, } \\
\text { DISTRIBUTION }\end{array}$ \\
\hline b. Dependent Variable: SALES & \\
\hline
\end{tabular}

In Table 1 Durbin Watson test 0.613 while the Durbin Watson table with dL 1.44625 and dU value 1.6283 indicate that there is a positive autocorrelation. In Table 2 Durbin Watson test 1,076 while the Durbin Watson table with $\mathrm{dL} 1.44625$ and dU value 1.6283 indicate that there is a positive autocorrelation.

\begin{tabular}{|c|c|c|c|c|c|}
\hline \multicolumn{3}{|c|}{ Table 3: $1^{\text {st }}$ Heteroscedasticity Test } & \multicolumn{3}{|c|}{ Table 4: $2^{\text {nd }}$ Heteroscedasicity Test } \\
\hline & Model & Sig. & & Model & Sig. \\
\hline \multirow[t]{4}{*}{1} & (Constant) & 0.78 & \multirow[t]{4}{*}{1} & (Constant) & 0.9 \\
\hline & DISTRIBUTION & 0.03 & & DISTRIBUTION & 0.89 \\
\hline & PROMOTION & 0 & & PROMOTION & 0.88 \\
\hline & & & & SALES & 0 \\
\hline
\end{tabular}

Source: SPSS

Table 3 the significant value is greater than $5 \%$ or 0.05 in the amount of 0.025 and 0.004 and it can be concluded that the data is homogeneous and there is no heteroscedasticity problem. Table 4 the significant value is greater than $5 \%$ or 0.05 in the amount of 0.888 and 0.881 and 0.000 and it can be concluded that the data is homogeneous and there is no heteroscedasticity problem.

\section{RESULTS AND DISCUSSIONS}

\begin{tabular}{|c|c|c|c|c|c|c|}
\hline \multicolumn{7}{|c|}{ Table 5: $1^{\text {st }}$ Regression coefficient } \\
\hline & & \multicolumn{3}{|c|}{ Standardized } & & \\
\hline & & Unstandardized Coefficients & Coefficients & & \\
\hline Model & & B & Std. Error & Beta & t & Sig. \\
\hline 1 & (Constant) & -4206108.697 & 4821162.272 & & -.872 & .387 \\
\hline & DISTRIBUTION & 3286632.372 & 1122221.685 & .394 & 2.929 & .005 \\
\hline & PROMOTION & -1.480 & 1.922 & -.104 & -.770 & 445 \\
\hline
\end{tabular}

a. Dependent Variable: SALES

$M=-4206108.697+3286632.372 X_{1}+1.922 X 2+e_{1}$ means, 
1) The constants in the equation - 4206108,697 with a negative direction, means if the independent variable equals zero, then the amount of sales will be reduced by 4206108,697 .

2) The regression coefficient of the distribution channel variable 3286632,372 with a positive direction, for every 1 unit increase in the number of distribution channels the sales will increase by 3286632,372 with other independent variables constant.

3) The regression coefficient of promotion cost variable is obtained by 1,480 with negative direction, this means that every 1 unit increase in the number of promotional costs, the sales will decrease by 1,480 with other independent variables constant.

Based on the first equation regression test the effect of the independent variable on the mediating variable shows that the significance value for the distribution variable is $0.005<0.05$ and the promotion cost variable is $0.445>0.05$.

\begin{tabular}{|c|c|c|c|c|c||c|}
\hline \multicolumn{7}{|c|}{ Table 6: 2nd Regression coefficient } \\
\hline & & \multicolumn{4}{|c|}{ Standardized } & \\
\hline & & Unstandardized Coefficients Coefficients & \\
\hline Model & & B & Std. Error & Beta & t & Sig. \\
& & & & & & \\
\hline 1 & (Constant) & -1.612 & 82.437 & & -.020 & .984 \\
\hline & DISTRIBUTION & .991 & 20.700 & .002 & .048 & .962 \\
\hline & PROMOTION & -0.000004 & .000 & -.003 & -.107 & .915 \\
\hline & SALES & 0.000069 & .000 & .975 & 27.979 .000 \\
\hline
\end{tabular}

a. Dependent Variable: MS

$Y=-1,612+0991 X_{1}--0.000004 X_{2}+0.000069 M+e_{2}$ means,

- The constant in the second equation is equal to -1.612 if the independent and mediating variables are equal to zero then the market share variable is 1,612

- The regression coefficient of the distribution channel variable is 0.991 with the positive direction indicates that for every 1 unit increase in the number of distribution channels, the market share will increase by 1,612 with other independent variables.

- The regression coefficient of the promotion cost variable is obtained by -0.000004 with negative direction indicates that every increase in the unit cost of promotion, the market share will decrease by 0.000004 with other independent variables constant.

- The regression coefficient of the variable sales obtained by 0.000069 with a positive direction, indicates that every increase in unit sales, the market share will increase by 0.000069 with other independent variables constant.

Table 7: $1^{\text {st }}$ Coefficient of Determination

\begin{tabular}{|c|c|c|c|c|}
\hline & & \multicolumn{3}{|c|}{ Adjusted RStd. Error of the } \\
\hline Model & R & R Square & Square & Estimate \\
\hline 1 & $.397 \mathrm{a}$ & .158 & .122 & 6425375.239 \\
\hline
\end{tabular}

a. Predictors: (Constant), PROMOTION, DISTRIBUTION

b. Dependent Variable: SALES
Table 8: $2^{\text {nd }}$ Coefficient of Determination

\begin{tabular}{|c|c|c|c|c|c|}
\hline & & & Adjusted R & $\begin{array}{c}\text { Std. Error of } \\
\text { the }\end{array}$ & \\
\hline Model & $\mathrm{R}$ & $\begin{array}{c}\mathrm{R} \\
\text { Square }\end{array}$ & Square & Estimate & $\begin{array}{c}\text { Durbin- } \\
\text { Watson }\end{array}$ \\
\hline 1 & .976 & .953 & .950 & 108.989 & 1.076 \\
\hline
\end{tabular}

a. Predictors: (Constant), SALES, PROMOTION, DISTRIBUTION

b. Dependent Variable: MS

It can be seen that the value of $\mathrm{R}^{2}$ for the first equation is 0.158 , which means that the ability of the independent variables which in this first equation is the distribution channel and promotion costs in explaining the dependent variable sales are only $15.8 \%$ and the remaining $84.2 \%$ is influenced by factors not examined in this study. The 
second equation where the distribution channel, promotion and sales as independent variables and market share variables produce a significant difference where the value of $\mathrm{R}^{2}$ is 0.953 which means that independent can influence the dependent variable namely market share of $95.3 \%$ and the remaining $4.7 \%$ is influenced by factors not examined in this study.

Table 9: $1^{\text {st }} \mathrm{t}$ test

\begin{tabular}{|c||c|c|}
\hline Model & $\mathrm{T}$ & Sig. \\
\hline (Constant) & -.872 & .387 \\
\hline DISTRIBUTIONI & 2.929 & .005 \\
\hline PROMOTION & -.770 & .445 \\
\hline a. Dependent Variable: SALES & & \\
\hline
\end{tabular}

Source: SPSS
Table 10: $2^{\text {nd }} \mathrm{t}$ test

\begin{tabular}{|c|c|c|}
\hline Model & $\mathrm{t}$ & Sig. \\
\hline (Constant) & -.020 & .984 \\
\hline DISTRIBUTION & .048 & .962 \\
\hline PROMOTION & -.107 & .915 \\
\hline SALES & 27.979 & .000 \\
\hline a. Dependent Variable: MS & & \\
\hline
\end{tabular}

T test Distribution Channels on Sales $\left(\mathrm{H}_{1}\right)$

The result $t$ count of distribution channel is 2,929 while the $t$ table is 2,687 then the value of $t$ count $>t$ table while the significance value of the distribution channel variable is 0.005 meaning $<0.05, \mathrm{H}_{1}$ can be accepted and it can be concluded that the distribution channel has a significant effect on sales.

T test Promotional Costs to Sales $\left(\mathrm{H}_{2}\right)$

The result $t$ count of promotion costs is 0.770 while the $t$ table is 2.687 then the value of $t$ table $<\mathrm{t}$ table, while the significance value of the promotion cost variable is 0.445 meaning $>0.05, \mathrm{H}_{2}$ is rejected and it can be concluded that the promotional cost does not have a significant effect on sales.

T test Sales to Market Share $\left(\mathrm{H}_{5}\right)$

The $t$ count of sales is 27,979 while the value of $t$ table is 2.687 then the value of $t$ count $>t$ table while the significance value of the sales variable is 0,000 meaning $<0.05, \mathrm{H}_{5}$ can be accepted and it can be concluded that the sales has a significant effect on market share.

Sobel Test

$$
\begin{aligned}
& t=\frac{a \times b}{\sqrt{b^{2} x S_{a}^{2}+a^{2} x S_{b}^{2}+S_{a}^{2} x S_{b}^{2}}} \\
& t=\frac{3286632.372 \times 0.000069}{\sqrt{0,000069^{2} x 1122221.685^{2}+3286632.372^{2} x 0.000002^{2}+1122221.685^{2} x 0.000002^{2}}} \\
& t=\frac{226,777633668}{\sqrt{5995,91537046326+43,2078093947132+5,037526041}} \\
& t=\frac{\mathbf{2 2 6 , 7 7 7 6 3 3 6 6 8}}{\sqrt{\mathbf{6 0 4 4 , 1 6 0 7 0 6}}} \\
& t=\frac{\mathbf{2 2 6 , 7 7 7 6 3 3 6 6 8}}{\mathbf{7 7 , 7 4 4 2 0 0 4 6}} \\
& t=\mathbf{2 , 9 1 6 9}
\end{aligned}
$$

The Effect of Distribution Channels on Market Share with Sales as an intervening variable $\left(\mathrm{H}_{3}\right)$.

Based on the calculation of $t$ count from the coefficient ab previously it was known that the $t$ table was 2.68701, and $t$ count $>t$ table with a number 2.9169> 2.687 which showed a positive result so it can be concluded that $\mathrm{H}_{3}$ was 
received and the number of distribution channels had a significant influence on the market share with sales as an intervening variable.

The Effect of Promotion Costs on Market Share with Sales as an intervening variable $\left(\mathrm{H}_{4}\right)$.

Based on the calculation of $t$ count from the ab coefficient previously known that the $t$ table of 2.68701, and these indicate $t$ count $>t$ table with a number of $0.00003>2.68701$ which shows a negative result so it can be concluded that $\mathrm{H}_{4}$ is rejected and the cost of promotion does not have a significant influence on the market share with sales as an intervening variable.

Effect Distribution Channels on Sales $\left(\mathrm{H}_{1}\right)$

The showed a significant influence between the distribution channel variables with sales, this is in accordance with the theory put forward by Royan (2009) that companies that can compete in marketing at this time are companies that can increase the number of marketing channels, because a single distributor has limitations among others, a smaller sales fleet, limited sales transactions and limited human resources, this is reinforced by previous research conducted by Mariatun (2017) that distribution channels have a significant effect on increasing sales but this is different from research conducted by Andelkovic , Barac and Radosavljevic (2017) who found no influence between distribution channels and sales in the retail goods industry in Serbia.

Effect Promotional Costs on Sales $\left(\mathrm{H}_{2}\right)$

The research for promotional costs show a significant negative effect on sales, this is contrary to the theory of Wirtz (2018) Service companies allocate more budget to the marketing aspect because it can increase sales and profits as well as prior research conducted by Aswin Syaharudin (2015) Significant Effect of Promotional Costs Against Increased Sales and Indra Suryawan's research (2017) promotion variable has no significant effect on sales volume,

Effect Distribution Channels on Market Share with Sales as an Intervening Variable $\left(\mathrm{H}_{3}\right)$

The of the study by measuring the indirect effect between the distribution channel variable on the market share variable and the sales outcome variable as an intervening variable show positive so that it can be concluded that the number of distribution channels has a significant influence on the market share with the sales as an intervening variable.

Effect Promotional Costs on Market Share with Sales as an Intervening Variable $\left(\mathrm{H}_{4}\right)$

The of the study of influence by measuring the indirect effect between the variable promotional costs to the market share variable with the sales outcome variable as an intervening variable shows negative so it can be concluded that the promotion costs do not have a significant effect on the market share with the sales as an intervening variable

Effect Sales on Market Share $\left(\mathrm{H}_{5}\right)$

The study for the effect of sales on market share showed a significant influence, this is in line with research conducted by Moutinho (1988) sales affect the growth of market share in retail companies in Scotland while Sungwook Min, Mary Wolfinbarger (2004) there was no influence between sales on the market share of the ecommerce industry in America.

\section{CONCLUSIONS AND RECOMMENDATIONS}

Based on the analysis conducted in this study, there are several conclusions:

The more number of distribution channels will increase the sales life insurance companies in Indonesia, the more varied distribution channels owned by the company the more target consumers can be reached so increase the life insurance service offered by users.

Increased promotional costs life insurance companies do not increase sales, this is because the promotional costs incurred by the company differ according to the target market and promotional activities carried out.

The number of distribution channels significantly influences the market share with sales as an intervening variable, this shows that an effective distribution channel can reach many target consumers which leads to the purchase of insurance services and can increase the percentage of the insurance company's market share.

Promotional costs do not significantly influence market share with sales as an intervening variable because promotional costs incurred by insurance companies differ according to the marketing strategy of the products they offer, so the total promotional costs cannot influence sales which directly affects the percentage of market share the insurance company. 
Growth in sales can affect the growth of market share in the insurance industry, this is because sales in the form of Net Premium Income is the main indicator of market share calculation so that the higher the amount, the higher the percentage of market share obtained.

Based on this study, here are several recommendations:

The next researcher should be able to analyze the effectiveness and sales on distribution channel used to determine which distribution channels are the most effective and most suitable for life insurance industry.

Further research is needed to develop a number of variables or add new types of variables to find out more about things that can affect market share and sales.

For life insurance companies to use more varied distribution channels in order to reach more consumers and to be more efficient in managing costs incurred for marketing in order to increase the company's sales.

\section{SOURCES OF FUNDING}

None.

\section{CONFLICT OF INTEREST}

None.

\section{ACKNOWLEDGMENT}

None.

\section{REFERENCES}

[1] Andelkovic, A., Barac, N., Radosajevic, M., (2017). Analysis of Distribution Channels successfulness The Case of The Retail Chains in The Republic of Serbia. Economic Themes55(4):501-519. https://econpapers.repec.org/article/vrsecothe/v_3a55_3ay_3a2017_3ai_3a4_3ap_3a501519_3an_3a4.htm

[2] Armstrong, G., \& Kotler, P. (2016). Marketing: An Introduction (13th Edition). New Jersey: Pearson Education LTD.

[3] Berkowitz, E., Kerin, R., Hartley, S., \& Rudelius, W. (2018). Marketing (6th Edition, Vol. 1-6). America: The McGraw-hill Companies.

[4] Maryatun \& Aryanti. (2017). Pengaruh Penerapan Saluran Distribusi Terhadap Tingkat Pendapatan pada Pengusaha Kripik Pisang Dikota Metro Tahun 2016 Jurnal Promosi 5(1) http://ojs.fkip.ummetro.ac.id/index.php/ekonomi/article/view/847

[5] Mathur, Sameer and Sinitsyn Maxim (2013) Price Promotions in Emerging Markets. International Journal of Industrial Organization 31(5) https://doi.org/10.1016/j.ijindorg.2013.07.001

[6] Moutinho, Luiz, (1988) “Is Your Company Planning Gains in Market share”. European Management Journal, 6(3), 209-215 https://doi.org/10.1016/S0263-2373(98)90005-6

[7] Min, Sungwook \& Wolfinbarger, Mary., (2004) Market share, profit margin, and marketing efficiency of early movers, bricks and clicks, and specialists in e-commerce". Journal of Business Research

58(8):1030-1039

https://www.researchgate.net/publication/4967226_Market_share_profit_margin_and_ma rketing_efficiency_of_early_movers_bricks_and_clicks_and_specialists_in_e-commerce

[8] Romadhona, Fajar (2017) Pengaruh Jumlah Kantor dan Biaya Promosi Terhadap Market Share Dengan Dana Pihak Ketiga (DPK) Sebagai Variabel Intervening pada Bank Umum Syariah dan Unit Usaha Syariah di Indonesia Periode 2013-2017. http://eprints.iain- surakarta.ac.id/3015/

[9] Royan, F. (2009). Distributorship Management. PT Gramedia Pustaka Utama.

[10] Suryawan, Indra (2017) Analisis Pengaruh Biaya Promosi Terhadap Peningkatan Volume Penjualan pada Perusahaan Timbangan "SSS” Surakarta. https://digilib.uns.ac.id 
[11] Sunyoto, D. (2013). Dasar-dasar Manajemen Pemasaran: Konsep, Strategi dan Kasus. (Edisi Pertama, Vol. 1-1). Yogyakarta: CLAPS.

[12] Swastha, B., \& Handoko, T. (2012). Manajemen Pemasaran Analisis Perilaku Konsumen. BFFE Yogyakarta.

[13] Syaharudin, Aswin (2015) Pengaruh Biaya Promosi Terhadap Peningkatan Penjualan Rumah Pada Perumahan Grand Aroepala di Makassar. Iqtisaduna 1 (2): 1-17 http://journal.uinalauddin.ac.id/index.php/Iqtisaduna/article/view/1191

[14] Vakratsas, Demetrios (2008) The Effect of Advertising, Price and Distribution on Market share Volatility. European Journal of Operational Research 187(1), 283-293 https://doi.org/10.1016/j.ejor.2007.02.034

[15] Wilbur, Kenneth C., Farris, Paul W., (2013). Distribution and Market Share. Journal of retailing. Journal of Retailing, https://papers.ssrn.com/sol3/papers.cfm?abstract_id=1175869 